\title{
Structural and mechanistic insights into s-block bimetallic catalysis: sodium magnesiate catalysed guanylation of amines
}

\author{
Marco De Tullio, ${ }^{[a]}$ Alberto Hernán-Gómez, ${ }^{[a]}$ Zoe Livingstone, ${ }^{[a]}$ William Clegg, ${ }^{[b]}$ Alan R. Kennedy, ${ }^{[a]}$ \\ Ross W. Harrington, ${ }^{[b]}$ Antonio Antiñolo, ${ }^{[c]}$ Antonio Martínez, ${ }^{[c]}$ Fernando Carrillo-Hermosilla*[c] and Eva \\ Hevia*[a]
}

\begin{abstract}
Advancing catalytic applications of s-block mixed-metal complexes, sodium magnesiate $\left[\mathrm{NaMg}\left(\mathrm{CH}_{2} \mathrm{SiMe}_{3}\right)_{3}\right](\mathbf{1})$ is reported as an efficient precatalyst for guanylation of a variety of anilines and secondary amines with carbodiimides. First examples of hydrophosphination of carbodiimides using a $\mathrm{Mg}$ catalyst are also described. The mixed-metal systems catalytic ability is much greater than those of its homometallic components $\left[\mathrm{NaCH}_{2} \mathrm{SiMe}_{3}\right]$ and $\left[\mathrm{Mg}\left(\mathrm{CH}_{2} \mathrm{SiMe}_{3}\right)_{2}\right]$. Stoichiometric studies suggest magnesiate amido and guanidinate complexes are intermediates in these catalyses. Reactivity and kinetic studies imply these guanylation reactions occur via (tris)amide intermediates that react with carbodiiimides in insertion steps. The rate law for the guanylation of $N, N^{\prime}$ diisopropylcarbodiimide with 4-tbutylaniline catalysed by 1 is order 1 in [amine], [carbodiimide] and [catalyst], showing a large kinetic isotopic effect, consistent with an amine-assisted rate-determining carbodiimide insertion transition state. Studies assessing the effect of sodium in these transformations denote a secondary role with little involvement in the catalytic cycle.
\end{abstract}

\section{Introduction}

Over the past decade, alkaline-earth metal catalysis has started to gain prominence, finding applications for heterofunctionalisation of a wide range of unsaturated organic fragments. ${ }^{[1]}$ Seminal contributions from the groups of Hill ${ }^{[2]}$ and Harder, ${ }^{[3]}$ amongst others, have added Group 2 metal complexes to the homogeneous catalytic landscape as lowtoxicity, low-cost alternatives to transition metal systems. Most initial applications have involved hydroamination of unsaturated organic substrates, including alkenes and alkynes, where

[a] M. De Tulio, Dr. A. Hernán-Gómez, Dr. Z. Livingstone, Dr. A. R. Kennedy, Prof. E. Hevia

WestCHEM, Department of Pure and Applied Chemistry

University of Strathclyde

295 Cathedral Street, Glasgow, UK, G1 1XL

eva.hevia@strath.ac.uk

[b] Prof. W. Clegg, Dr. R. W. Harrington

School of Chemistry

Newcastle University

Newcastle upon Tyne, UK, NE1 7RU

[c] Prof. A. Antiñolo, A. Martínez, Dr. F. Carrillo-Hermosilla Centro de Innovación en Química Avanzada (ORFEO-CINQA) Departamento de Química Inorgánica, Orgánica y Bioquímica, Facultad de Ciencias y Tecnologías Químicas, Universidad de Castilla-La ManchaCampus Universitario, E-13071 Ciudad Real, Spain

Fernando.Carrillo@uclm.es

Supporting information for this article is given via a link at the end of the document. heavier $\mathrm{Ca}$ or $\mathrm{Sr}$ complexes have demonstrated remarkable catalytic capabilities. ${ }^{[4]}$ In contrast, success using Mg has been more limited as its smaller radius raises transition state barriers in rate-determining alkene insertion steps, showing similar patterns to those previously noticed with organolanthanide (III) catalysts. ${ }^{[5]}$ Starting to overturn this trend, we have shown recently that $\mathrm{Mg}$ activated within a sodium magnesiate platform, can outperform $\mathrm{Ca}$ and $\mathrm{Ba}$ systems in hydroaminating isocyanates, securing higher yields and superior substrate scope under milder conditions. ${ }^{\left[{ }^{[]}\right.}$Cooperative effects between the two metals underpin this catalytic transformation, ${ }^{[7]}$ with Lewis acidic $\mathrm{Na}$ anchoring and activating the isocyanate enabling intramolecular attack by the highly nucleophilic Lewis basic tris(amido) magnesiate, facilitating a synergistic scenario which is not available in the aforementioned single-metal systems.

Building on these initial findings, and on previous studies on alkali-metal magnesiate chemistry, which have already demonstrated the unique synergistic properties of these bimetallic systems (e.g., enhanced reactivity, special regioselectivities, excellent functional group tolerance) in several cornerstone stoichiometric transformations, ${ }^{[8]}$ here we assess the ability of sodium magnesiates to catalyse guanylation of amines with carbodiimides (Scheme 1).

The synthesis of guanidines has received considerable attention, ${ }^{[9]}$ as these simple nitrogen-containing molecules are valuable building blocks present in numerous natural products and pharmaceuticals. ${ }^{[10]}$ Furthermore, they also find extensive applications as precursors of ancillary ligands for numerous transition, lanthanoid, and main group metal complexes ${ }^{[11]}$ and they can also be employed as organocatalysts. ${ }^{[12]}$ Atomeconomical catalytic addition of amines to carbodiimides (guanylation reaction, Scheme 1) constitutes one of the most straightforward routes to access $\mathrm{N}$-substituted guanidines. ${ }^{[9]}$<smiles>[R]N=C(N[R])N[R]</smiles>

Scheme 1. Guanylation of primary amines with carbodiimides.

Although certain guanylations can be accomplished catalyst-free, these processes have high kinetic barriers requiring the use of harsh reaction conditions as well as restricting their applications to activated primary aliphatic amines. ${ }^{[13]}$ Thus, metal-catalysis is required when using anilines or secondary amines, and even so, 
high temperatures are needed, with only a select few catalytic systems facilitating these processes at room temperature. ${ }^{[9]}$

The vast majority of these studies have focussed on transitionmetal and rare-earth metal catalysis. ${ }^{[14]}$ Notwithstanding, some recent studies using lithium, ${ }^{[15,16 a]}$ or magnesium (and heavier group 2 elements ${ }^{[16,17]}$ have already demonstrated the potential of s-block metal complexes to catalyse these reactions. Related studies investigating the synthesis of phosphaguanidines have revealed the ability of heavier alkaline-earth metal amides to catalyse the direct addition of secondary phosphines to carbodiimides. ${ }^{[18]}$

Aiming to expand the scope of s-block cooperative catalysis, here we report the first catalytic applications of alkali-metal magnesiates for the synthesis of guanidines. Combining kinetic experiments with stoichiometric reactivity studies, we provide informative mechanistic insights into these new ate-catalysed transformations.

\section{Results and Discussion}

\section{Catalytic synthesis of guanidines and phosphaguanidines}

We began our studies testing the efficacy of homoleptic sodium magnesiate $\left[\mathrm{NaMg}\left(\mathrm{CH}_{2} \mathrm{SiMe}_{3}\right)_{3}\right](1)^{[19]}$ in the intermolecular hydroamination reaction of different carbodiimides with a variety of aromatic, aliphatic and secondary cyclic amines (guanylation process). In addition, we have tested compound $\mathbf{1}$ in the hydrophosphination reaction of the same carbodiimide substrates with the secondary phosphine $\mathrm{Ph}_{2} \mathrm{PH}$ (Scheme 2).



Scheme 2. Catalytic guanylation and hydrophosphination reactions

Firstly, we studied as a model reaction, the guanylation of 2,6dimethylaniline $\mathbf{2 f}$ with $N, N^{\prime}$-diisopropylcarbodiimide (DIC) 3a (Table 1), in $\mathrm{C}_{6} \mathrm{D}_{6}$, using 2 mol\% of 1 . At room temperature, the reaction yielded $90 \%$ of the corresponding guanidine $4 \mathrm{~h}$ in 3 hours. An important solvent effect was noted and when the more polar ethereal solvent $d_{8}$-THF, with its greater coordination ability, was employed, guanidine $\mathbf{4 h}$ was obtained in a $99 \%$ yield after just 15 minutes. Contrastingly, illustrating the synergic reactivity of 1 , when its single-metal components were tested as catalysts under the same reaction conditions lower conversions for guanidine $\mathbf{4 h}$ were observed after 15 minutes, with $\mathrm{Mg}\left(\mathrm{CH}_{2} \mathrm{SiMe}_{3}\right)_{2}$ being significantly less efficient (44\% conversion) than the more polar, more reactive $\mathrm{NaCH}_{2} \mathrm{SiMe}_{3}$ (72\% conversion) (Table 1). This noticeable influence of the metals contrasts with recent studies by Harder, employing a naked $\left\{\mathrm{NPh}_{2}\right\}^{-}$anion as an organocatalyst. ${ }^{[3 a]}$

\begin{tabular}{|c|c|c|c|c|}
\hline Entry & Catalyst (2 mol\%) & Solvent & Time (h) & $\begin{array}{l}\text { Yield } \\
(\%)^{a}\end{array}$ \\
\hline \multirow{2}{*}{1} & \multirow{2}{*}[\mathrm{NaCH}_{2}\mathrm{SiMe}_{3}]{} & \multirow{2}{*}{$\mathrm{d}_{8}-\mathrm{THF}$} & 0.25 & 72 \\
\hline & & & 1 & 84 \\
\hline \multirow{2}{*}{2} & \multirow{2}{*}[\mathrm{Mg}(\mathrm{CH}_{2}\mathrm{SiMe}_{3})_{2}]{} & \multirow{2}{*}{$\mathrm{d}_{8}-\mathrm{THF}$} & 0.25 & 44 \\
\hline & & & 16 & 99 \\
\hline 3 & {$\left[\mathrm{NaMg}\left(\mathrm{CH}_{2} \mathrm{SiMe}_{3}\right)_{3}\right]$ (1) } & $\mathrm{d}_{8}-\mathrm{THF}$ & 0.25 & 99 \\
\hline 4 & {$\left[\mathrm{NaMg}\left(\mathrm{CH}_{2} \mathrm{SiMe}_{3}\right)_{3}\right](1)$} & $\mathrm{C}_{6} \mathrm{D}_{6}$ & 3 & 90 \\
\hline
\end{tabular}

[a] Yields obtained via spectroscopic ${ }^{1} \mathrm{H}$ NMR integration of signals for the guanidine product $4 \mathrm{~h}$ with addition of ferrocene $(10 \mathrm{~mol} \%)$ as internal standard. Reactions carried out using $0.5 \mathrm{~mL}$ of solvent, $0.55 \mathrm{mmol}$ of 2,6 dimethylaniline, $0.5 \mathrm{mmol}$ of DIC, and $0.01 \mathrm{mmol}$ of catalyst.

Subsequently, the catalytic activity of 1 was investigated for a range of amines and carbodiimides (Table 2, see also Experimental Section). Aniline (2a) reacts with $N, N^{\prime}$ diisopropylcarbodiimide DIC (3a), N,N'-dicyclohexylcarbodiimide (DCC) (3b), and EtNCNEt (3c), affording guanidines 4a-c in high yields ( $80 \%$ to $96 \%$, Table 2 , entries $1-3$ ). It is noteworthy that precatalyst 1 was compatible with both electron-donating and electron-withdrawing substituents on the phenyl ring of the amine such as Me-, t-butyl-, MeO-, or Cl- (Table 2, entries 4-7) affording the corresponding substituted guanidines $\mathbf{4 d - 4 g}$ in excellent yields (80-98\%). Furthermore, 1 also effectively facilitated the room temperature addition of hindered anilines with substituents at their ortho-positions (2f-2g) or even of the secondary aniline $\mathrm{N}$-methylaniline $\mathbf{( 2 h )}(\mathbf{8 6}-94 \%$ yield, Table 2 , entries 8, 9, and 10) and low activated diphenylamine (2i) $(73 \%$ yield, Table 2, entry 11). Interestingly, and despite the presence of a pyridyl substitutent, which could potentially coordinate to the bimetallic intermediates involved in this process, inhibiting their catalytic activity, the reaction of 3 -aminopyridine $(2 \mathbf{j})$ with DIC afforded guanidine $4 \mathrm{I}$ in an $88 \%$ yield (Table 2, entry 12). This versatility and functional tolerance are remarkable when compared with other s-block catalytic systems where anilines with large substituents or coordinating groups give lower yields than when employing non-substituted substrates. ${ }^{9 c,} 15$ Using cyclic amines, morpholine and piperidine, and $n$-butylamine required the used of forcing reaction conditions, higher temperatures $\left(70{ }^{\circ} \mathrm{C}\right)$, or a longer reaction time $(24 \mathrm{~h})$, to furnish the relevant guanidines $4 \mathrm{~m}-4 \mathrm{o}$ in moderate yields $(52-65 \%$, Table 2, entries 13-15). Contrastingly no reaction is observed when diisopropylamine $(\mathbf{2 n})$ is employed which can be rationalised in terms of the significant increase steric bulk in this amine and its relatively low acidity when compared with the rest of the substrates studied (Table 2, entries 16). Although previous studies have shown the feasibility of homometallic magnesium complexes to catalyse guanylation processes 
employing, unhindered amines, ${ }^{[16 a, 16 b]} 1$ offers a significant improvement for secondary amines and substituted anilines, ${ }^{[16 a, 16 c]}$ enabling these processes to take place at room temperature in short periods of time. Interestingly, hydrophosphination of carbodiimides 3a-c with diphenylphosphine (2o) could also be achieved at room temperature using catalyst loadings as low as $2 \mathrm{~mol} \%$, affording the relevant phosphoguanidines $\mathbf{4 q - 4 s}$ in high yields (80-95\%, Table 2, entries 17-19). To the best of our knowledge, this represents the first example of a magnesium complex catalysing this process, showing an activity comparable to those reported by Hill using heavier alkaline earth metal amides, where efficiency of the catalyst correlates directly with the increase in size of the metal cation. ${ }^{[18]}$

Table 2. Guanylation and hydrophosphination of carbodiimides. ${ }^{[a]}$

\begin{tabular}{lll}
\hline Entry & Amine/Phos \\
\hline &
\end{tabular}

CyN= C = NCy

(3b)

(3a)

$=\mathrm{N}^{\mathrm{P}} \mathrm{Pr}$

$\mathrm{EtN}=\mathrm{C}=\mathrm{NEt}$

(3c)

4<smiles>Cc1ccc(N)cc1</smiles>

5



6<smiles>Nc1ccc(Cl)cc1</smiles>

(3a)<smiles>CCCCCCCC=[N+]=N</smiles>

(3a)

$$
\begin{aligned}
& \text { Compound/Yield } \\
& (\%)^{\mathrm{b}}
\end{aligned}
$$

11<smiles>c1ccc(Nc2ccccc2)cc1</smiles>

(2i)
$\mathrm{CyN}=\mathrm{C}=\mathrm{NCy}$

(3b)

<smiles>[AlH2]NC(=NC1CCCCC1)N(c1ccccc1)c1ccccc1</smiles>

$4 k /(73)$

Table 2. Continuation. ${ }^{[a]}$

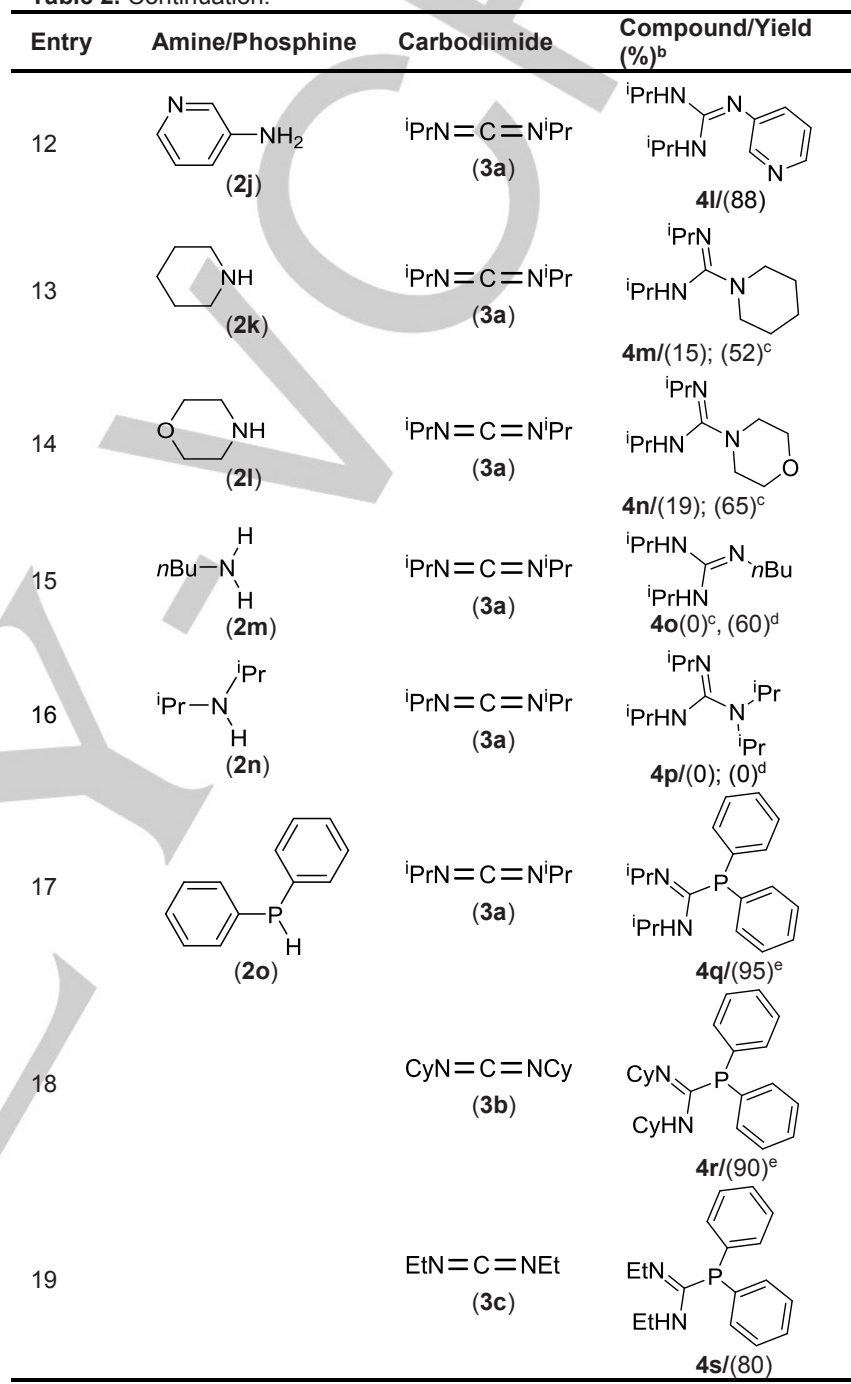

[a] Conditions: amine/phosphine $(1.00 \mathrm{mmol})$, carbodiimide $(1.00 \mathrm{mmol})$, catalyst $1(2 \% \mathrm{~mol}), \operatorname{THF}(3 \mathrm{~mL}), 1 \mathrm{~h}, 25^{\circ} \mathrm{C}$. [b] Isolated yields. [c] $1 \mathrm{~h}, 70^{\circ} \mathrm{C}$. [d] $24 \mathrm{~h}, 70^{\circ} \mathrm{C}$. [e] $30 \mathrm{~min}, 25^{\circ} \mathrm{C}$.

\section{Stoichiometric Studies}

To gain mechanistic insights into these promising catalytic processes a series of stoichiometric reactions were carried out. Addition of three molar equivalents of $\mathrm{NH}_{2} \mathrm{Ar}\left(\mathrm{Ar}=2,6-\mathrm{Me}_{2} \mathrm{C}_{6} \mathrm{H}_{3}\right)$ (2f) to tris(alkyl)magnesiate 1 afforded colourless crystals of tris(amido)magnesiate $\left[\left\{(\mathrm{THF})_{3} \mathrm{NaMg}\left(\mathrm{NHAr}_{3}\right)\right\}_{2}\right]$ (5) in a $58 \%$ yield (Scheme 3).

10

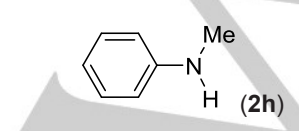

'PrN $=\mathrm{C}=\mathrm{N}$ 'Pr

(3a)

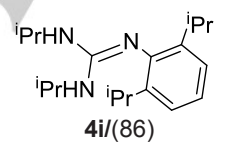

PrHN 


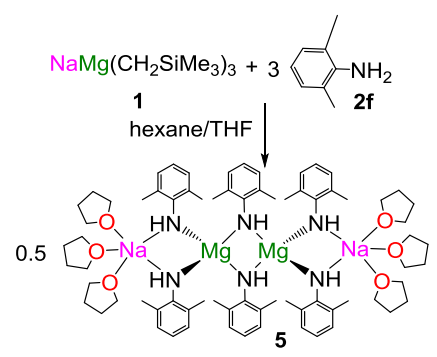

Scheme 3. Synthesis of sodium magnesiate $\mathbf{5}$.

Determined by X-ray crystallography, the molecular structure of 5 is dimeric, comprising a tetranuclear $\mathrm{Na}$...Mg...Mg...Na chain arrangement connected by six anilide bridges. ${ }^{[21]}$ This gives rise to three planar four-membered rings made up of two outer $\left\{\mathrm{NaN}_{2} \mathrm{Mg}\right\}$ heterometallic rings, which are linked through a central $\left\{\mathrm{Mg}_{2} \mathrm{~N}_{2}\right\}$ homometallic ring, that is orthogonal to the outer rings. Each $\mathrm{Mg}$ atom in $\mathbf{5}$ is bonded to four amido groups with $\mathrm{Mg}-\mathrm{N}$ distances similar [mean value, 2.08(5) $\AA$ ] to those found in other reported tris(amido) alkali-metal magnesiates. ${ }^{[21]}$ Three molecules of THF complete the coordination sphere of each sodium atom which is also coordinated by two amido groups, exhibiting Na-N distances [mean value, 2.54(4) A] which are significantly elongated compared to that reported for the homometallic sodium anilide $\left[\{(\mathrm{PMDETA}) \mathrm{NaNHPh}\}_{2}\right][$ mean value 2.42(3) A]. ${ }^{[22]}$ The structure of $\mathbf{5}$ contrasts to that previously reported by us for $\left[(\mathrm{THF})_{2} \mathrm{NaMg}\left(\mathrm{NPh}_{2}\right)_{3}\right]$ (6). Resulting from a similar reaction of 1 with three equivalents of diphenylamine, 6 displays a monomeric arrangement with the amido groups coordinating terminally to $\mathrm{Mg}$ via their $\mathrm{N}$ atoms; whereas the $\mathrm{Na}$ center $\pi$-engages with two phenyl groups in addition to binding to two THF ligands. ${ }^{[6]}$

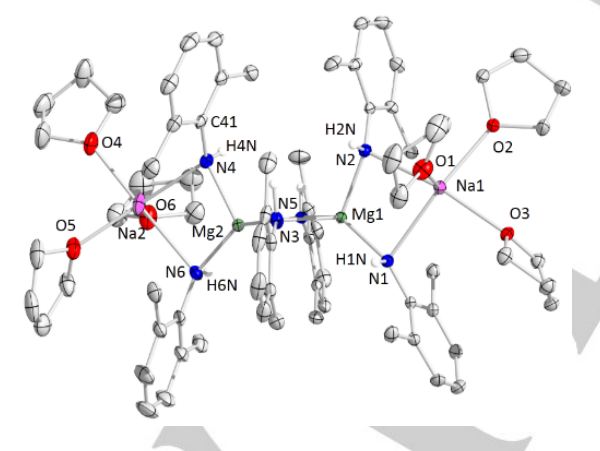

Figure 1. Molecular structure of $\left[\left\{(\mathrm{THF})_{3} \mathrm{NaMg}\left(\mathrm{NAr}_{3}\right)\right\}_{2}\right]$ (5) with displacement ellipsoids at the $30 \%$ probability level. Disorder and hydrogen atoms except those attached to nitrogen atoms are omitted for clarity. Selected bond distances $(\AA)$ and angles (०), Mg(1)-N(1) 2.032(2), Mg(1)-N(2) 2.051(2), Mg(1)$\mathrm{N}(3)$ 2.159(2), Mg(1)-N(5) 2.111(2), Mg(2)-N(3) 2.078(2), Mg(2)-N(4) 2.057(2), $\mathrm{Mg}(2)-\mathrm{N}(5)$ 2.160(2), $\mathrm{Mg}(2)-\mathrm{N}(6)$ 2.028(2), Na(1)-N(1) 2.590(2), Na(1)-N(2) 2.539(2), $\mathrm{Na}(1)-\mathrm{O}(1) 2.40(2), \mathrm{Na}(1)-\mathrm{O}(2)$ 2.362(2), Na(1)-O(3) 2.356(2), $\mathrm{Na}(2)-$ $\mathrm{N}(4)$ 2.488(2), $\mathrm{Na}(2)-\mathrm{N}(6)$ 2.562(2); N(1)-Mg(1)-N(2) 105.38(9), N(1)-Mg(1)$\mathrm{N}(3)$ 106.75(9), N(1)-Mg(1)-N(5) 136.73(9), N(2)-Mg(1)-N(3) 102.89(8), N(2)$\mathrm{Mg}(1)-\mathrm{N}(5)$ 109.60(8), N(3)-Mg(1)-N(5) 89.58(7), N(3)-Mg(2)-N(4) 107.65(9), $\mathrm{N}(3)-\mathrm{Mg}(2)-\mathrm{N}(5) \quad 90.45(8), \quad \mathrm{N}(3)-\mathrm{Mg}(2)-\mathrm{N}(6) \quad 137.49(9), \quad \mathrm{N}(4)-\mathrm{Mg}(2)-\mathrm{N}(5)$ 101.10(9), N(4)-Mg(2)-N(6) 105.43(9), N(5)-Mg(2)-N(6) 108.59(8).
Multinuclear NMR spectroscopy characterization of compound $\mathbf{5}$ was performed in $\mathrm{C}_{6} \mathrm{D}_{6}$ solution. ${ }^{1} \mathrm{H}$ NMR analysis (Figure S5), revealed a complex spectrum with multiple signals in the aromatic, aliphatic and $\mathrm{NH}$ regions. More informatively, the ${ }^{13} \mathrm{C}$ NMR spectrum showed six different signals (ranging from 157.0 to $152.7 \mathrm{ppm}$ ) which can be assigned to the ipso-C atoms of the 2,6- $-\mathrm{Me}_{2}-\mathrm{C}_{6} \mathrm{H}_{4}$ groups (Figure S6), suggesting the lack of equivalence between the anilide groups present in $\mathbf{5}$. This is consistent with retention in $\mathrm{C}_{6} \mathrm{D}_{6}$ solution of the dimeric structure of $\mathbf{5}$ in the solid state, with six non-equivalent anilide fragments, derived from four chiral nitrogen atoms and two pro-chiral nitrogen atoms. ${ }^{[23]}$ Further confirmation of the retention of the dimeric arrangement of 5 in $\mathrm{C}_{6} \mathrm{D}_{6}$ solution was gained by ${ }^{1} \mathrm{H}$ DOSY NMR studies (see Supporting Information). Thus, investigation of a deuterated toluene solution of 5 (40 mM), using tetramethylsilane (TMS) as an internal reference, revealed D (diffusion coefficient) values of $5.076 \mathrm{e}^{-10} \mathrm{~m}^{2} / \mathrm{s}$ and $2.262 \mathrm{e}^{-09}$ $\mathrm{m}^{2} / \mathrm{s}$ respectively (Figure $\mathrm{S} 7$ ). Using the external calibration curve (ECC) for dissipated spheres and ellipsoids elaborated by Stalke ${ }^{[24]}$ the molecular weight of compound $\mathbf{5}$ in solution was estimated to be $1183 \mathrm{~g} \mathrm{~mol}^{-1}$. This result deviates only $5 \%$ when compared to the dimeric structure observed for $\mathbf{5}$ in the solid state. Interestingly, using donor $\mathrm{d}_{8}$-THF as solvent, DOSY experiments indicate the formation of solvent-separated ion pair species (Scheme 4). In this case two different diffusion coefficients were observed for $5\left(D_{1}=6.864 \mathrm{e}^{-10} \mathrm{~m}^{2} / \mathrm{s}\right.$ and $D_{2}=$ $\left.5.929 \mathrm{e}^{-10} \mathrm{~m}^{2} / \mathrm{s}\right)$. From these values two molecular weights were calculated $\left(\mathrm{Mw}_{1}=773 \mathrm{~g} \mathrm{~mol}^{-1}\right.$ and $\left.\mathrm{Mw}_{2}=994 \mathrm{~g} \mathrm{~mol}^{-1}\right)$ which are consistent with the presence in solution of monoanionic $\left[(\mathrm{THF})_{3} \mathrm{NaMg}_{2}(\mathrm{NHAr})_{6}\right]^{-}(5 \mathrm{~A})(\mathrm{Mw}=769.66 \mathrm{~g} / \mathrm{mol})$ and dianionic $\left[\mathrm{Mg}_{2}(\mathrm{NHAr})_{6}\right]^{2-}(5 \mathrm{~B})(\mathrm{Mw}=1008.97 \mathrm{~g} / \mathrm{mol})$ species $(1 \%$ error for both species). ${ }^{[25]}$ Furthermore 2D $\left[{ }^{1} \mathrm{H}-{ }^{1} \mathrm{H}\right]$ EXSY NMR data (Figures $\mathrm{S} 10$ and $\mathrm{S} 11$ ) established that slow exchange takes place between $\mathbf{5 A}$ and $\mathbf{5 B}$ in $\mathrm{d}_{8}$-THF solution.

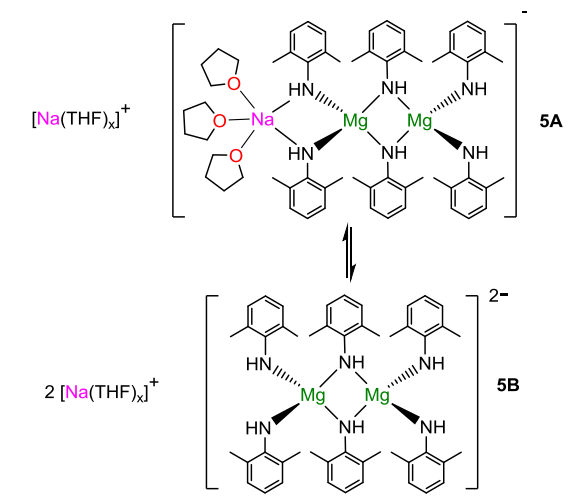

Scheme 4 Proposed magnesiate species $5 A$ and $5 B$ observed in $d_{8}-\mathrm{THF}$ solution.

${ }^{1} \mathrm{H}$ NMR monitoring of the reaction of an equimolar mixture of carbodiimide $\mathbf{3 a}$ and aniline $\mathbf{2} \mathbf{f}$ in the presence of $2 \mathrm{~mol} \%$ of tris(amido) magnesiate $\mathbf{5}$ indicated the formation of guanidine $4 \mathrm{~h}$ in a $99 \%$ yield after 15 minutes at room temperature, 
showing an identical efficiency to that found for tris(alkyl)magnesiate 1 (99\%, Table 1, entry 3$)$. This hints at a possible involvement of (amido)magnesiate $\mathbf{5}$ as an intermediate in the catalytic cycle (vide supra). If this is the case, the higher catalytic activity of $\mathbf{1}$ in donor solvent THF when compared with benzene (Table 1) can be rationalized in terms of the different constitution of the relevant tris(amido) ate species in these solvents, with THF favouring the formation of solvent-separated- ion pair (SSIP) species which can be anticipated to be more powerful nucleophiles (containing terminal $\mathrm{Mg}-\mathrm{N}$ bonds) than the analogous contacted-ion pair (CIP) ates where all the ligands are bridging between two metals.

We next investigated the insertion reactions of tris(amido) magnesiates $\mathbf{6}$ and 5 with three molar equivalents of carbodiimide $\mathbf{3 b}$ and $\mathbf{3 a}$ respectively (Schemes 5 and 6 respectively). Interestingly, completely different outcomes were observed depending on the amido group present on the magnesiate. Thus, 6, containing diphenylamido groups, can insert only two molecules of carbodiimide $\mathbf{3 b}$, affording heteroleptic mixed amido/guanidinate sodium magnesiate $\mathbf{7}$ in a $78 \%$ yield (Scheme 5). Contrastingly, 5 can react effectively with three equivalents of $\mathbf{3 a}$ furnishing a $1: 1$ mixture of the homometallic magnesium and sodium guanidinates $\mathbf{8}$ and $\mathbf{9}$, which contain the unsymmetrical guanidinate ligand ['PrNC(NH'Pr)NAr], resulting from the formal insertion of the carbodiimide into the $\mathrm{N}-\mathrm{H}$ bonds of the anilide groups present in 5 (Scheme 6). ${ }^{[26]}$ The formation of ['PrNC(NHiPr)NAr] can be rationalised as a result of a proton transfer from the arylamino nitrogen atom to an isopropylamido nitrogen, followed by the dissociation of the resultant $\mathrm{NH}^{\mathrm{P}} \mathrm{Pr}$ group and formation of a new M-NAr bond (where $\mathrm{M}=\mathrm{Mg}$ or $\mathrm{Na}$ ). This isomerization not only allows a better stabilization of the negative charge of the ligand (due to the conjugation effect between the aromatic ring and the $\mathrm{C}=\mathrm{N}$ bond), but also a relief on the steric hindrance around the metal, by replacing one bulky NiPr arm of the guanidinate ligand by a NAr substituent. ${ }^{[27]}$ Conversion of 5 into a 1:1 mixture of $\mathbf{8}$ and $\mathbf{9}$ occurs quantitatively, as indicated by ${ }^{1} \mathrm{H}$ NMR monitoring of the reaction. Compound 8 could be crystallised from the reaction mixture in a $38 \%$ yield. Compound $\mathbf{9}$ could alternatively be prepared by insertion of $\mathbf{3 b}$ in sodium amide $\left[\left\{(\mathrm{THF})_{2} \mathrm{Na}(\mathrm{NHAr})\right\}_{2}\right](10)$ (see experimental details in Supporting Information).



Scheme $\mathbf{5}$ Insertion reaction of $\mathbf{3 b}$ with tris(amido) magnesiate $\mathbf{6}$.
These results suggest that under stoichiometric conditions, in the case of $\mathbf{5}$, the insertion of a third equivalent carbodiimide into the remaining anilide group induces the disproportionation of putative magnesiate $\left[\left\{\mathrm{Na}(\mathrm{THF})_{\times}\right]\left[\mathrm{Mg}\left\{\operatorname{PrNC}\left(\mathrm{NH}^{\mathrm{i}} \mathrm{Pr}\right) \mathrm{NAr}\right\}_{3}\right]\right.$ into its monometallic guanidinate components $\mathbf{8}$ and $\mathbf{9}$. This process is probably driven by the large steric congestion around $\mathrm{Mg}$ when coordinated by three guanidinate ligands. Attempts to prepare the relevant products of insertion resulting from the reactions of one and two equivalents of DIC with $\mathbf{5}$ furnished, in all cases, variable amounts of 8 and 9 (in a 1:1 ratio) along with the recovery of unreacted $\mathbf{5}$. Thus under the conditions of this study, it appears that the three-fold activation of the Mg-NHAr bonds of 5 is significantly favoured over a possible sequential reactivity. Contrastingly, sodium magnesiate 7 does not react with a further equivalent of carbodiimide even under forcing reaction conditions $\left(12 \mathrm{~h}, 60^{\circ} \mathrm{C}\right)$. This lack of reactivity can be attributed to the steric congestion around $\mathrm{Mg}$ in $\mathbf{7}$, which should compromise not only the approach of the heterocumulene to the magnesiate anion but also the availability of the remaining $\mathrm{NPh}_{2}$ amido group to act as a nucleophile, with its $\mathrm{N}$ atom sheltered by the cyclohexyl scaffolding of the guanidinate ligands (see Figure $2 b$ for a space filling model) which is also further stabilized by delocalization of its lone pair across its two Ph substituents (sum of the angles around N7, $359.9^{\circ}$, see Figure 2a).



Scheme 6 Insertion reaction of 3a with tris(amido) magnesiate 5

X-ray crystallographic studies established the molecular structures of 7, 8 and 9 (Figures 2, 3, and 4 respectively). Sodium magnesiate 7 exhibits a SSIP structure, comprising a sodium cation solvated by THF molecules balanced by a magnesiate anion where the magnesium center is bound by two chelating guanidinate ligands and a terminal $\mathrm{NPh}_{2}$ group (Figure 2a). The five coordinate $\mathrm{Mg}$ center displays a distorted square planar pyramidal geometry [ $\Sigma$ bond angles around base $\left.=338^{\circ}\right]$, with the $\mathrm{NPh}_{2}$ ligand occupying the apical position (Figure 2a). 

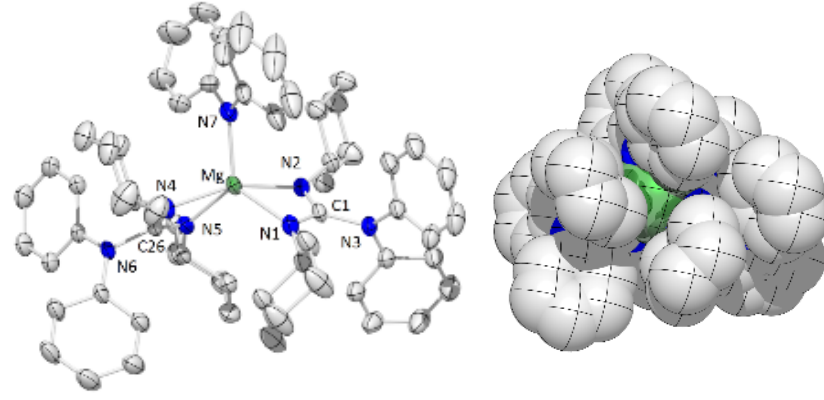

Figure 2: (a) Molecular structure of the anion $\left[\mathrm{Mg}\left\{(\mathrm{CyN})_{2} \mathrm{C}\left(\mathrm{NPh}_{2}\right)\right\}_{2}\left(\mathrm{NPh}_{2}\right)\right]^{-}$ present in 7 with displacement ellipsoids at the $30 \%$ probability level. Hydrogen atoms are omitted for clarity. (b) Space filling model for this anion. Selected bond distances $(\AA)$ and angles ( $\left.{ }^{\circ}\right) \mathrm{Mg}-\mathrm{N}(1)$ 2.116(3), $\mathrm{Mg}-\mathrm{N}(2)$ 2.194(3), Mg-N(4) 2.178(3), Mg-N(5) 2.130(3), N(1)-C(1) 1.326(5), N(1)-Mg$\mathrm{N}(7)$ 120.16(15), N(2)-C(1) 1.299(5), N(3)-C(1) 1.440(5), N(4)-C(26) 1.304(5), $\mathrm{N}(5)-\mathrm{C}(26)$ 1.309(5), N(6)-C(26) 1.469(4), N(1)-Mg-N(2) 62.4(1), N(1)-Mg$\mathrm{N}(5)$ 114.8(1), N(2)-Mg-N(4) 160.9(1), N(2)-Mg-N(7) 100.0(1), N(4)-Mg-N(5) 62.5(1), N(4)-Mg-N(7) 99.0(1), N(5)-Mg-N(7) 125.1(1).

Although, as far as we are aware, 7 constitutes the first example of an alkali-metal magnesiate containing guanidinate ligands to be structurally defined, the structure of the magnesiate anion bears a strong resemblance to that found for homometallic magnesium complex 8 (Figure 3), though in this case the apical position is filled by a molecule of the neutral donor THF. Related structures to that of $\mathbf{8}$ have recently being reported by Kays for magnesium guanidinates obtained using an alternative synthetic approach, by $\mathrm{MgnBu}_{2}$ deprotonation of guanidines containing highly sterically demanding groups. ${ }^{[28,29]}$ It should also be noted that the guanidinate ligands present in $\mathbf{8}$ are unsymmetrical, with one of the chelating N' atoms attached to 'Pr (N1), whereas the remaining $N(N 2)$ binds to 2,6-dimethylphenyl (Ar) (vide supra). This lack of symmetry, translates in the formation of noticeably shorter Mg-NR bonds when $\mathrm{R}={ }^{\mathrm{i}} \operatorname{Pr}[2.066(2) \AA]$ than for the aromatic substituent $[2.158(2) \AA]$.

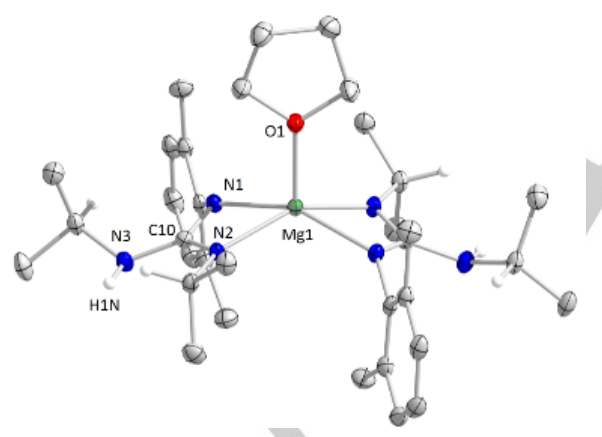

Figure 3 Molecular structure of $\left[\mathrm{Mg}\left\{\left({ }^{\mathrm{P}} \mathrm{PrNC}(\mathrm{NAr})\right\}(\mathrm{HN} \mathrm{Pr})\right\}_{2}(\mathrm{THF})\right](\mathbf{8})(\mathrm{Ar}=2,6$ $\mathrm{Me}_{2} \mathrm{C}_{6} \mathrm{H}_{3}$ ) with displacement ellipsoids at the $30 \%$ of probability. Hydrogen atoms, except those attached to nitrogens and those from the $\mathrm{CH}$ groups of the isopropyl substituents, are omitted for clarity. Selected bond distances $(\AA)$ and angles ( $\left.{ }^{\circ}\right) \mathrm{Mg}(1)-\mathrm{O}(1)$ 2.039(2), $\mathrm{Mg}(1)-\mathrm{N}(1)$ 2.158(2), $\mathrm{Mg}(1)-\mathrm{N}(2)$ 2.066(2), $\mathrm{N}(1)-\mathrm{C}(10)$ 1.344(3). $\mathrm{N}(2)-\mathrm{C}(10)$ 1.326(3), N(3)-C(10) $1.385(3), \mathrm{N}(3)-\mathrm{H}(1 \mathrm{~N})$ 0.84(4); O(1)-Mg(1)-N(1) 163.65(6), O(1)-Mg(1)-N(2) 104.94(7), N(1)-Mg(1)$\mathrm{N}(2) 64.01(8), \mathrm{N}(2)-\mathrm{Mg}(1)-\mathrm{N}\left(1^{\prime}\right)$ 108.45(8).
Sodium guanidinate 9 shows a dimeric arrangement, with the two guanidinate ligands being parallel to each other (Figure 4). Each sodium is coordinated by four $\mathrm{N}$ atoms of the $\mathrm{Na}_{2} \mathrm{~N}_{4}$ core [distances ranging from $2.453(1)$ to $2.558(2) \AA$ ] as well as a molecule of THF, with a Na...Na1 vector of length 2.671(2) $\AA$, which lies perpendicular to the two guanidinate NCN planes. Containing the same unsymmetrical guanidinate ligand described above for 8, an opposite trend is observed for the length of its $\mathrm{Na}-\mathrm{N}$ bonds [Na-N1, 2.453(1) $\AA$ vs Na-N2, 2.558(2) $\AA]$. The structure of 9 contrasts with that reported for trimeric guanidinate complex $\left\{\mathrm{Na}\left[\mathrm{CyNC}\left(\mathrm{N}\left(\mathrm{SiMe}_{3}\right)_{2}\right) \mathrm{NCy}\right]\right\}_{3}$, resulting from the reaction of $\mathrm{DCC}$ with $\mathrm{NaN}\left(\mathrm{SiMe}_{3}\right)_{2}{ }^{[30]}$

Protonolysis of guanidinate complexes 7-9 was attempted by treating them with variable amounts of the relevant amine (two equivalents of $\mathrm{NHPh}_{2}$ for 7 , and two and one equivalents of $\mathrm{NH}_{2} \mathrm{Ar}$ for 8 and 9 respectively). In all cases, no reaction was apparent after 24 hours at room temperature. The catalytic ability of these guanidinate complexes was also investigated. Interestingly, mixed-metal guanidinate 7 was able to catalyse the guanylation of DCC with $\mathrm{NHPh}_{2}$ affording guanidine in almost identical yields to those found when using sodium magnesiate 1 (73\% vs $75 \%$ using in both cases 2 mol\% catalyst loading, RT, 1h). However, illustrating the synergistic capabilities in sodium magnesiate systems, single-metal guanidinates $\mathbf{8}$ and $\mathbf{9}$ displayed significant lower efficiencies for the reaction of DIC and $\mathrm{NH}_{2} \mathrm{Ar}$ than 1. Thus $\mathrm{Mg}$ complex 8 afforded guanidine product in a modest $30 \%$ after 15 minutes, whereas the $\mathrm{Na}$ complex 9 gave a $72 \%$ conversion under the same conditions. Even when an equimolar mixture of $\mathbf{8}$ and $\mathbf{9}$ was employed as a catalyst for this reaction (using a $2 \mathrm{~mol} \%$ loading, room temperature, 15 minutes), the conversions observed were still lower $(76 \%)$ than when using preformed bimetallic precatalyst 1 $(99 \%)$. Collectively these results, and despite the isolation of single metal complexes in some of the stoichiometric studies, support the view that these guanylation reactions are indeed ate-catalysed transformations and highlight the limitations of comparing the results of stoichiometric reactions with the complex equilibria present during the catalytic process where variable excesses of reagents are present.



Figure 4. Molecular structure of $\left[\mathrm{Na}\{(\operatorname{PrNC}(\mathrm{NAr})(\mathrm{HN} \mathrm{Pr})\}(\mathrm{THF})]_{2}(\mathrm{Ar}=2,6\right.$ $\left.\mathrm{Me}_{2} \mathrm{C}_{6} \mathrm{H}_{3}\right)(\mathrm{THF})_{2}$ ] (9) with displacement ellipsoids at the $30 \%$ of probability Hydrogens atoms except those attached to nitrogens and those from the $\mathrm{CH}$ groups of the isopropyl substituents, are omitted for clarity. Selected bond distances $(\AA)$ and angles $\left(^{\circ}\right) \mathrm{Na}(1)-\mathrm{O}(1) 2.277(1), \mathrm{Na}(1)-\mathrm{N}(1) 2.453(1), \mathrm{Na}(1)-$ 
$\mathrm{N}(2)$ 2.558(2), $\mathrm{N}(1)-\mathrm{C}(5)$ 1.341(2), $\mathrm{N}(2)-\mathrm{C}(5)$ 1.323(2), N(3)-C(5) 1.404(2), $\mathrm{N}(3)-\mathrm{H}(1 \mathrm{~N}) \quad 0.9(2) ; \quad \mathrm{O}(1)-\mathrm{Na}(1)-\mathrm{N}(1) \quad 122.19(4), \quad \mathrm{O}(1)-\mathrm{Na}(1)-\mathrm{N}(2) \quad 123.79(4)$ $\mathrm{O}(1)-\mathrm{Na}(1)-\mathrm{N}\left(1^{\prime}\right) \quad 122.27(5), \quad \mathrm{O}(1)-\mathrm{Na}(1)-\mathrm{N}\left(2^{\prime}\right) \quad 120.48(4), \quad \mathrm{N}(1)-\mathrm{Na}(1)-\mathrm{N}(2)$ 53.57(4), N(2)-Na(1)-N(1') 89.20(5), N(2')-Na(1)-N(1) 93.88(5), N(1)-C(5)-N(2) 116.0(1), N(1)-C(5)-N(3) 120.4(1), N(2)-C(5)-N(3) 123.5(1).

\section{Mechanistic Studies}

The observations from our stoichiometric studies, together with knowledge obtained from previous reports using s-block singlemetal catalysts, ${ }^{[9]}$ suggest that these ate-catalysed guanylation reactions of amines may take place via the mechanism presented in Scheme 7. Initially fast protonation of sodium tris(alkyl) magnesiate $\mathbf{1}$ takes place to form a nucleophilic sodium tris(amido) magnesiate (as those seen for $\mathbf{5}$ and $\mathbf{6}$ ), that in turn can undergo carbodiimide insertion affording a sodium magnesiate guanidinate complex. Protonolysis of this latter species with one equivalent of amine liberates the guanidine product and regenerates the active sodium tris(amido) magnesiate.

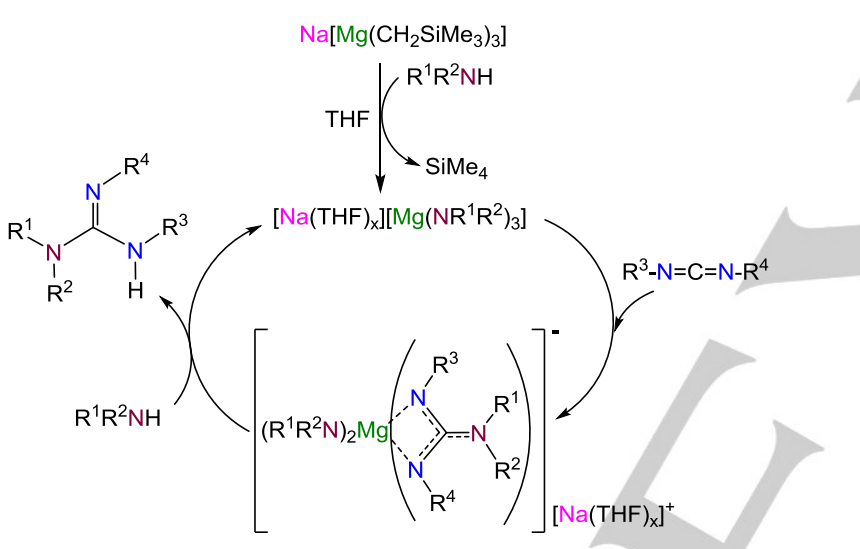

Scheme 7. Proposed mechanism for the guanylation of anilines with 1.

Previous insightful mechanistic studies by Richeson using LiHMDS as a catalyst have shown that the insertion step in these processes is initiated by coordination of the carbodiimide to the Lewis acidic $\mathrm{Li}$ center. ${ }^{[31]}$ Using bimetallic 1 as a precatalyst, two potential sites are available for coordination, involving either the $\mathrm{Na}$ or $\mathrm{Mg}$ centers. Repeating the guanylation of DIC (3a) by 2,6-dimethylaniline (2f) using as a catalyst a 1:1 mixture of sodium magnesiate 1 and the crown ether 15-crown-5 (which can block $\mathrm{Na}$ coordination sites) showed only a slight decrease in the yield obtained for guanidine $4 \mathrm{~h}$ (from $99 \%$ to $83 \%)$, which, coupled with the DOSY studies that show preference of these bimetallic compounds to exist as SSIP structures in THF solutions, suggest only a secondary role for sodium in this process, with the pre-coordination of the carbodiimide to $\mathrm{Mg}$. Consistent with this interpretation of a minor involvement of the alkali-metal, rather than stabilising the magnesiate anion, using the lithium derivative $\left[\mathrm{LiMg}\left(\mathrm{CH}_{2} \mathrm{SiMe}_{3}\right)_{3}{ }^{\left[{ }^{32}\right]}\right.$ as a precatalyst led to almost identical conversions $(97 \%)$ to those observed using sodium-containing 1. Thus, the enhanced catalytic activity of these bimetallic systems seems to be a case of anionic activation, ${ }^{[33]}$ where the formation of magnesiate anions, generates more powerful nucleophilic intermediates than when using charge-neutral organomagnesium precursors. ${ }^{[16]}$

In order to obtain quantitative kinetic data, reactions of $N, N^{\prime}$ diisopropylcarbodiimide with 4-tbutylaniline in the presence of 1 as catalyst were carried out, using $\mathrm{d}_{8}$-THF as solvent. Reaction rates of the guanylation were monitored over time by ${ }^{1} \mathrm{H}$ NMR spectroscopy using the integration changes in the substrate resonances over more than three half-lives. We first determined the order of the reaction with respect to amine concentration by keeping the concentration of other components virtually unaltered. Initially, the study started by using $2 \mathrm{~mol} \%$ of catalyst $\mathbf{1}$, and the carbodiimide to amine molar ratio was maintained at 10:1 to maintain approximately zero-order conditions for carbodiimide. The plot of $\ln \left([\mathrm{A}]_{0} /[\mathrm{A}]_{\mathrm{t}}\right)$ versus reaction time is shown in Figure 5 , where $[A]_{0}$ is the initial amine concentration and $[A]_{t}$ is the amine concentration after a given reaction time. An induction period was not observed, indicating that the catalyst was reactive from the beginning of the process. The data confirm a fit consistent with first-order kinetic behaviour with respect to amine concentration.



Figure 5. First-order kinetic analysis of the NMR-tube scale reaction of 4tbutylaniline ( $\mathbf{-}$ ) or 4-tbutylaniline- $\mathrm{d}^{2}(\bullet)$ and di-isopropylcarbodiimide in $\mathrm{d}_{8}$-THF with $2 \mathrm{~mol} \%$ of 1 at room temperature.

Next, we determined the order of the reaction with respect to the concentration of carbodiimide. During this study we maintained a relative carbodiimide to amine ratio of $1: 10$, and the linearity of the plot of $\ln \left([\mathrm{C}]_{0} /[\mathrm{C}]_{\mathrm{t}}\right)$, where $[\mathrm{C}]$ is the carbodiimide concentration, versus the reaction time shows that the reaction was also first-order with respect to this reagent (Figure S22). Additionally, we carried out a H/D kinetic isotope effect (KIE) experiment using $N, N$ '-diisopropylcarbodiimide and 4-tertbutylaniline- $d_{2}$ with catalyst 1 . This study gave a KIE $\left(k_{H} / k_{D}\right)$ value of 5 (Figure 5). The maximum calculated kinetic isotope effect (KIE) at $25{ }^{\circ} \mathrm{C}$ for a reaction involving a $\mathrm{N}-\mathrm{H}$ bond should be approximately 8.5 . In our case of the guanylation reaction of tert-butylaniline, the magnitude of the measured value was clearly indicative of a primary $\mathrm{KIE},{ }^{[34]}$ and indicates that a $\mathrm{N}-\mathrm{H}$ bond is broken during the turnover-limiting step. While this observation would indicate that protonolysis by the amine of the starting alkyl compound could be the rate-determining step, it seems unlikely as stoichiometric reactions demonstrate that 
these protolytic reactions occur instantaneously at room temperature. Thus, the more limiting protonolysis of chelate guanidinate intermediates could be responsible for this high KIE. The dependence of the rate of reaction with respect to catalyst concentration was studied with different catalyst precursor concentrations, [1] = $1-5 \mathrm{~mol} \%$, and fixing the carbodiimide to amine molar ratio at 10:1. A plot of reaction rate versus catalyst concentration reveals a linear increase of the reaction rate with catalyst concentration (Figure 6 left).


Figure 6. Plot of reaction rate versus concentration of the catalyst (left) and van't Hoff plot (right).

The first order rate of the reaction with respect to the catalyst concentration was further confirmed from the van't Hoff plot for the three first concentrations (Figure 6 right). The value of the slope was determined to be close to 1 . Thus, from the present study, the overall rate law for the guanylation of 4-tbutylaniline with $N, N^{\prime}$-diisopropylcarbodiimide catalyzed by 1 at low concentrations could be summarized as shown in eqn (1). A similar rate law has been obtained for trinuclear zirconium alkyl diamido complexes. ${ }^{[34]}$

rate $=\mathrm{k}[\text { amine }]^{1}\left[\right.$ carbodiimide $^{1}\left[\right.$ catalyst $^{1}(1)$

Values of $k_{o b s}$ at four different temperatures were measured. These $k_{o b s}$ values satisfactorily fit the Arrhenius plot (Figure 8, left), with a value of $E_{a}=20.7 \mathrm{~kJ} \cdot \mathrm{mol}^{-1}$. The activation parameters were quantified by a plot of $\ln \left(\mathrm{k}_{\text {obs }} / \mathrm{T}\right)$ versus $1 / \mathrm{T}$, which results in $\Delta \mathrm{H}^{\neq}=18.1 \mathrm{~kJ} \cdot \mathrm{mol}^{-1}$ and $\Delta \mathrm{S}^{\neq}=-25.8 \mathrm{~J} \cdot \mathrm{mol}^{-1} \cdot \mathrm{K}^{-1}$ (Figure 8 , right). ${ }^{[35]}$ This last value could support the existence of a concerted transition state. Although the kinetic studies of guanylation process are scarce, ${ }^{16 a, 35}$ several authors propose an amine-assisted concerted transition state in comparatively analogous alkene hydroamination processes with group 2 metal complexes, involving, as in this case, a large isotopic effect. ${ }^{[36]}$ This amine-assisted state could also explain the first order observed in amine (and carbodiimide), in such a way that, under catalytic conditions, where an excess of amine is present through the main part of the process, we propose that the magnesium amido complex formed in the first step could coordinate an amine molecule, where the negatively charged nitrogen atom of the incoming carbodiimide was stabilized favouring the attack of an amido ligand on the electrophilic carbon atom (Figure 7).

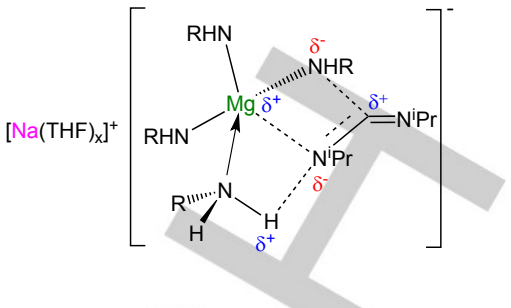

Figure 7. Proposed carbodiimide insertion transition state.
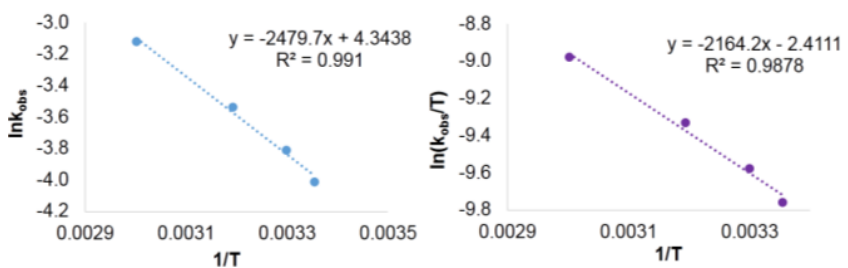

Figure 8. Arrhenius (left) and Eyring plots (right) for the guanylation reaction catalysed by 1 .

\section{Conclusions}

We report here the first catalytic applications of alkali-metal magnesiates for guanylation and hydrophosphination reactions. Homoleptic mixed $\mathrm{Na} / \mathrm{Mg}$ complex $\left[\mathrm{NaMg}\left(\mathrm{CH}_{2} \mathrm{SiMe}_{3}\right)_{3}\right]$ (1) has been found to offer significantly greater catalytic ability than those of its homometallic components $\left[\mathrm{NaCH}_{2} \mathrm{SiMe}_{3}\right]$ and $\left[\mathrm{Mg}\left(\mathrm{CH}_{2} \mathrm{SiMe}_{3}\right)_{2}\right]$, allowing guanylation of a range of substituted anilines and secondary amines under very mild reaction conditions (most cases at room temperature). Furthermore, by installing $\mathrm{Mg}$ within this sodium magnesiate platform, it is possible to activate it towards catalysing the hydrophosphination of carbodiimides at room temperature.

Stoichiometric investigations have allowed the isolation and structural elucidation of tris(amido) sodium magnesiate $\left[\left\{(\mathrm{THF})_{3} \mathrm{NaMg}\left(\mathrm{NHAr}_{3}\right)\right\}_{2}\right] \quad$ (5) and mixed amido/guanidinate sodium magnesiate $\left[\mathrm{Na}(\mathrm{THF})_{5}\right]^{+}\left[\mathrm{Mg}\left\{(\mathrm{CyN})_{2} \mathrm{C}\left(\mathrm{NPh}_{2}\right)\right\}_{2}\left(\mathrm{NPh}_{2}\right)\right]^{-}$(7). These appear to be intermediates in these catalytic transformations. Reactivity studies in these complexes, coupled with kinetic investigations, suggest these guanylation reactions occur by forming highly nucleophilic (tris)amide intermediates that can subsequently react with the carbodiiimide in an insertion step, followed by amine protonolysis of the resultant guanidinate species. Interestingly, all these processes appear to take place in the coordination sphere of $\mathrm{Mg}$, with $\mathrm{Na}$ taking a backseat in the catalytic cycle, stabilising the magnesiate anion intermediates, hinting that the enhanced catalytic activity of these systems is due to anionic activation.

The rate law for the guanylation of $N, N^{\prime}$-diisopropylcarbodiimide with 4-tbutylaniline catalysed by 1 was deduced to be order 1 in [amine], [carbodiimide] and [catalyst], showing a large kinetic isotopic effect, which is consistent with the formation of an amine-assisted rate-determing carbodiimide insertion transition state. 


\section{Experimental Section}

General Considerations. All reactions were performed under a protective argon atmosphere using standard Schlenk techniques. Hexane, benzene and THF were dried by heating to reflux over sodium benzophenone ketyl and distilled under nitrogen or they were passed through a column of activated alumina (Innovative Tech.), degassed under nitrogen and stored over molecular sieves in the glove-box prior to use. $\quad \mathrm{Mg}\left(\mathrm{CH}_{2} \mathrm{SiMe}_{3}\right)_{2}, \quad \mathrm{NaCH}_{2} \mathrm{SiMe}_{3}, \quad\left[\mathrm{NaMg}\left(\mathrm{CH}_{2} \mathrm{SiMe}_{3}\right)_{3}\right]$ and $\left[(\mathrm{THF})_{2} \mathrm{NaMg}\left(\mathrm{NPh}_{2}\right)_{3}\right]$ were prepared according to the literature. ${ }^{[6,19,37]}$ $\mathrm{LiCH}_{2} \mathrm{SiMe}_{3}$, amines, phosphines and carbodiimides were purchased from Sigma Aldrich chemicals and used as received. NMR spectra were recorded on a Bruker DPX400 $\mathrm{MHz}$ spectrometer, operating at 400.13 $\mathrm{MHz}$ for ${ }^{1} \mathrm{H}, 100.62 \mathrm{MHz}$ for ${ }^{13} \mathrm{C}$ or on a Varian $\mathrm{FT}-400$ spectrometer using standard VARIAN-FT software. Elemental analyses were carried out using a Perkin Elmer 2400 elemental analyzer.

Preparative Scale Reaction of the guanidines and phosphaguanidines. In the glovebox, a solution of compound 1 (2\% $\mathrm{mol})$ in THF (3 mL) was added in a Schlenk tube. Amine (or phosphane) $(1.00 \mathrm{mmol})$ and carbodiimide $(1.00 \mathrm{mmol})$ were then added to the above reaction mixture. The Schlenk tube was taken outside the glovebox, and the reaction was stirred at the desired temperature. After carrying out the reaction for the desired time, the solution was concentrated under reduced pressure, and hexane was added and placed in a refrigerator at $-30{ }^{\circ} \mathrm{C}$ for $16 \mathrm{~h}$. After filtration the products were obtained as white microcrystalline solids, characterized by comparing their NMR spectra with the literature data. ${ }^{[14 e, 16 a, 27,38]}$

X-ray crystallography. Data for samples $\mathbf{5 , 8}$ and $\mathbf{9}$ were measured on Oxford Diffraction diffractometers ${ }^{[39]}$ with Mo Ka $(\lambda=0.71073 \AA)$ or Cu Ka $(\lambda=1.5418 \AA)$. Data for sample 7 were measured at Beamline 119 of the Diamond Light Source using $0.6889 \AA$ radiation and a Crystal Logics diffractometers with Rigaku Saturn 724+ CCD detector; data collection and processing used Rigaku and Bruker software. All structures were refined to convergence on $F^{2}$ of all independent reflections by the fullmatrix least-squares method using the SHELXL program. ${ }^{[40]}$ Selected crystallographic and refinement details are given in the supporing information Table S1.

Synthesis of $\left[\left\{(\mathrm{THF})_{3} \mathrm{NaMg}(\mathrm{NHAr})_{3}\right\}_{2}\right]$ (5) $\left(\mathrm{Ar}=2,6-\mathrm{Me}_{2} \mathrm{C}_{6} \mathrm{H}_{3}\right)$. To a $\mathrm{NaMg}\left(\mathrm{CH}_{2} \mathrm{SiMe}_{3}\right)_{3}(1 \mathrm{mmol}, 0.309 \mathrm{~g})$ suspension in hexane $(10 \mathrm{~mL}) 2,6-$ dimethylaniline $(3 \mathrm{mmol}, 0.37 \mathrm{~mL}$ ) was added. After $1 \mathrm{~h}$ stirring at room temperature THF ( $2 \mathrm{~mL})$ was introduced, affording a light brown solution. The solution was stored at $-20{ }^{\circ} \mathrm{C}$ overnight affording colorless crystals of sodium magnesiate 5 (0.362 g, 58\%). ${ }^{1} \mathrm{H}$ NMR $\left(400 \mathrm{MHz}, 298 \mathrm{~K}, \mathrm{C}_{6} \mathrm{D}_{6}\right) \delta$ $(\mathrm{ppm})=1.24(\mathrm{~m}, 24 \mathrm{H}, \mathrm{THF}), 1.87,1.98,2.07,2.18,2.19,2.22\left(36 \mathrm{H}, \mathrm{CH}_{3}\right.$, $\mathrm{NHAr}), 2.52,2.57,2.68,2.76,2.79,2.81$ (6H, NHAr), 3.19 (m, 24H, THF), 6.3-7.1 (18H, CH, NHAr). ${ }^{13} \mathrm{C}$ NMR $\left(100 \mathrm{MHz}, 298 \mathrm{~K}, \mathrm{C}_{6} \mathrm{D}_{6}\right) \delta(\mathrm{ppm})=$ 18.8, 19.5, 19.7, 20.0, 20.9, $21.6\left(\mathrm{CH}_{3}, \mathrm{NH} A r\right), 25.5$ (THF), 67.8 (THF), $111.7,111.8,112.3,112.6,116.6,121.4,121.7,122.0,124.7,125.3$, 125.9, 128.6, 128.9, 129.0, 129.1, 129.3, 129.5, 129.8 ( $\mathrm{CH}, \mathrm{NH} A r), 152.7$ 152.8, 156.1, 156.2, 156.6,157 (ipso-C, NHAr). Anal Calcd for $\mathrm{C}_{72} \mathrm{H}_{108} \mathrm{Mg}_{2} \mathrm{~N}_{6} \mathrm{Na}_{2} \mathrm{O}_{6}: \mathrm{C}, 69.28 ; \mathrm{H}, 8.72 ; \mathrm{N}, 6.73$. Found, C, 69.25; $\mathrm{H}$, $8.85 ; \mathrm{N}, 7.12$.

Synthesis of $\left[\mathrm{Na}(\mathrm{THF})_{5}\right]^{+}\left[\mathrm{Mg}\left\{(\mathrm{CyN})_{2} \mathrm{C}\left(\mathrm{NPh}_{2}\right)\right\}_{2}\left(\mathrm{NPh}_{2}\right)\right]^{-}(7)$. To a THF solution $(4 \mathrm{~mL})$ of sodium magnesiate $\left[(\mathrm{THF})_{2} \mathrm{NaMg}\left(\mathrm{NPh}_{2}\right)_{3}\right](6)(0.7 \mathrm{~g}, 1$ mmol) N,N'-dicyclohexylcarbodiimide (DCC) (3a) $(0.62 \mathrm{~g}, 3 \mathrm{mmol})$ was added. After $1 \mathrm{~h}$ stirring, hexane $(4 \mathrm{~mL})$ was introduced, and the Schlenk was stored in the freezer $\left(-30^{\circ} \mathrm{C}\right)$ overnight to allow the formation of colorless crystals of $\left[\mathrm{Na}(\mathrm{THF})_{5}\right]^{+}\left[\mathrm{Mg}\left\{(\mathrm{CyN})_{2} \mathrm{C}\left(\mathrm{NPh}_{2}\right)\right\}_{2}\left(\mathrm{NPh}_{2}\right)\right]^{-}(7)(1.03 \mathrm{~g}$, $78 \%) .{ }^{1} \mathrm{H}$ NMR $\left(400 \mathrm{MHz}, 298 \mathrm{~K}, \mathrm{C}_{6} \mathrm{D}_{6}\right) \delta(\mathrm{ppm})=1.04-1.27,1.47-1.73(\mathrm{~m}$, $\left.40 \mathrm{H}, \mathrm{CH}_{2}, \mathrm{CyN}\right), 1.43(\mathrm{~m}, 2 \mathrm{H}, \mathrm{THF}),-3.40-4.48$ (m, 4H, CH, CyN), 3.57 $(\mathrm{m}, 2 \mathrm{H}, \mathrm{THF}), 6.71\left(\mathrm{t}, \mathrm{J}=7.1 \mathrm{~Hz}, 1 \mathrm{H}, \mathrm{N} P h_{2}\right), 6.79\left(\mathrm{t}, \mathrm{J}=7.1 \mathrm{~Hz}, 1 \mathrm{H}, \mathrm{N} P h_{2}\right)$, 6.85-6.90 (m, 4H, CH, NPh, guanidinate), 7.16-7.23, (m, 8H, CH, NPh, guanidinate), 7.28-7.38 (m, 4H, CH, NPh $), 7.44\left(\mathrm{~d}, \mathrm{~J}=7.6 \mathrm{~Hz}, 8 \mathrm{H}, \mathrm{N} P h_{2}\right.$ guanidinate), 7.50 (d, J=7.6 Hz, 2H, NPh2), 7.67 (d, J=7.6 Hz, 2H, $\mathrm{NPh} 2) .{ }^{13} \mathrm{C}$ NMR $\left(100 \mathrm{MHz}, 298 \mathrm{~K}, \mathrm{C}_{6} \mathrm{D}_{6}\right) \delta(\mathrm{ppm})=25.7$ (THF), 26.2, 26.5, 26.6, 26.8, 37.3, 37.4, ( $\left.\mathrm{CH}_{2}, \mathrm{CyN}\right) 55,56.1(\mathrm{CH}, \mathrm{CyN}), 67.9$ (THF), 121.1, 129.3, $130.2\left(\mathrm{CH}, \mathrm{N} P h_{2}\right.$, guanidinate), 145.8 (ipso-C, NPh guanidinate), 122, 129.5, $130.3(\mathrm{CH}, \mathrm{NPh} 2), 146.3$ (ipso- $\mathrm{C}, \mathrm{NPh}$ ), 163.5 $\left(\mathrm{CN}_{3}\right)$. Anal Calcd for $\mathrm{C}_{82} \mathrm{H}_{114} \mathrm{MgN}_{7} \mathrm{NaO}_{5}$ : C, 74.32; $\mathrm{H}, 8.67 ; \mathrm{N}, 7.40$ Found, C, 74.48; $\mathrm{H}, 8.41 ; \mathrm{N}, 8.37$.

Stoichiometric studies: reaction between $\left[\left\{(\mathrm{THF})_{3} \mathrm{NaMg}\left(\mathrm{NHAr}_{3}\right)\right\}_{2}\right](5)$ $\left(\mathrm{Ar}=\mathbf{2 , 6}-\mathrm{Me}_{2} \mathrm{C}_{6} \mathrm{H}_{3}\right.$ ) and 3 equivalents of diisopropylcarbodiimide (3a). Sodium magnesiate $\left[\left\{(\mathrm{THF})_{3} \mathrm{NaMg}\left(\mathrm{NHAr}_{3}\right)\right\}_{2}\right]$ (5) $(0.312 \mathrm{~g}, 0.25 \mathrm{mmol})$ was reacted with $\mathrm{N}, \mathrm{N}$-diisopropylcarbodiimide $(1.5 \mathrm{mmol}, 0.23 \mathrm{~mL})$ in THF ( $2 \mathrm{~mL})$. The reaction mixture was stirred for 1 hour, then hexane (4 $\mathrm{mL}$ ) was added (if a precipitate forms, it can be redissolved by gentle heating). The solution was stored at $-15{ }^{\circ} \mathrm{C}$ overnight to allow the formation of colorless crystals of compound $\left[\mathrm{Mg}\{(\mathrm{PrN}) \mathrm{C}(\mathrm{NAr})(\mathrm{HN} \mathrm{Pr})\}_{2}(\mathrm{THF})\right](8)(112 \mathrm{mg}, 38 \%) .{ }^{1} \mathrm{H}$ NMR $(400 \mathrm{MHz}$ $298 \mathrm{~K}, \mathrm{~d}_{8}$-THF) $\delta(\mathrm{ppm})=0.56\left(\mathrm{~d}, \mathrm{~J}=6.2 \mathrm{~Hz}, 12 \mathrm{H}, \mathrm{CH}_{3}, \mathrm{iPr}\right), 0.79$ (d, $\mathrm{J}=6.4 \mathrm{~Hz}, 12 \mathrm{H}, \mathrm{CH}_{3}$, $\left.\mathrm{i} \mathrm{Pr}\right), 1.77$ (m, 4H, THF), 2.19 (s, 12H, $\mathrm{CH}_{3}, \mathrm{NAr}$ ) 3.02-3.15 (m, 4H, CH, $\mathrm{Pr}), 3.61$ (m, 4H, THF) 3.80 (br d, 2H, NH'Pr), 6.56 (t, J=7.6 Hz, 2H, para-CH, NAr), 6.80 (d, J=7.6 Hz, 4H, meta-CH, $\mathrm{NAr}) .{ }^{13} \mathrm{C}$ NMR $\left(100 \mathrm{MHz}, 298 \mathrm{~K}, \mathrm{~d}_{8}-\mathrm{THF}\right) \delta(\mathrm{ppm})=19.7\left(\mathrm{CH}_{3}, \mathrm{NAr}\right)$, $24.2\left(\mathrm{CH}_{3},{ }^{\mathrm{i}} \mathrm{Pr}\right), 25\left(\mathrm{CH}_{3},{ }^{\mathrm{i}} \mathrm{Pr}\right), 26.2$ (THF), $44.7\left(\mathrm{CH},{ }^{\mathrm{i}} \mathrm{Pr}\right), 45.0\left(\mathrm{CH},{ }^{\mathrm{i}} \mathrm{Pr}\right)$, 68.0 (THF), 120.1 (para- $\mathrm{CH}, \mathrm{NAr}$ ), 128.1 (meta- $\mathrm{CH}, \mathrm{NAr}$ ), 132.6 (ortho- $\mathrm{C}$ $\mathrm{NAr}$ ), 150.3 (ipso-C, NAr), $163.5\left(\mathrm{CN}_{3}\right)$. Anal Calcd for $\mathrm{C}_{34} \mathrm{H}_{56} \mathrm{MgN}_{6} \mathrm{O}: \mathrm{C}$, 69.31; H, 9.58; N, 14.26. Found, C, 68.73; H, 9.26; N, 13.97.

Synthesis of $[\mathrm{Na}\{(\mathrm{PrN}) \mathrm{C}(\mathrm{NAr})(\mathrm{HN} \mathrm{Pr})\}(\mathrm{THF})]_{2}(9)\left(\mathrm{Ar}=2,6-\mathrm{Me}_{2} \mathrm{C}_{6} \mathrm{H}_{3}\right)$ To a solution of sodium (2,6-dimethylphenyl)amide [ $\left.\{\mathrm{Na}(\mathrm{NHAr})\}_{2}\right]$ (10) $(0.143 \mathrm{~g}, 0.5 \mathrm{mmol})$ in hexane/THF $(4 \mathrm{~mL} / 1 \mathrm{~mL})$ diisopropylcarbodiimide $(0.08 \mathrm{~mL}, 0.5 \mathrm{mmol})$ was added. The resulting pale yellow solution was stored in the freezer $\left(-30^{\circ} \mathrm{C}\right)$ overnight to allow the formation of colorless crystals of $[\mathrm{Na}\{(\mathrm{iPrN}) \mathrm{C}(\mathrm{NAr})(\mathrm{HNiPr})\}(\mathrm{THF})]_{2}$ (9) $(0.108 \mathrm{~g}, 63 \%) .{ }^{1} \mathrm{H}$ NMR $(400 \mathrm{MHz}, 298 \mathrm{~K}, \mathrm{~d} 8-\mathrm{THF}) \delta(\mathrm{ppm})=0.91\left(\mathrm{~s}, 24 \mathrm{H}, \mathrm{CH}_{3}\right.$, $\left.\mathrm{Pr}\right), 1.78(\mathrm{~m}, 4 \mathrm{H}$, THF), 2.11 (s, 6H, CH $\mathrm{CH}_{3} \mathrm{NAr}$ ), 3.30 (broad s, $4 \mathrm{H}+2 \mathrm{H}, \mathrm{CH}$, $\mathrm{i} \mathrm{Pr}+\mathrm{N} H^{\prime} \mathrm{Pr}$ ), 3.61 (m, 4H, THF), 6.26 (t, J=7.2 Hz, 2H, para-CH, NAr), 6.69 (d, J=7.2 $\mathrm{Hz}, 4 \mathrm{H}$, meta-CH, NAr). ${ }^{13} \mathrm{C}$ NMR $\left(100 \mathrm{MHz}, 298 \mathrm{~K}, \mathrm{~d}_{8}-\mathrm{THF}\right) \delta(\mathrm{ppm})=$ $19.8\left(\mathrm{CH}_{3}, \mathrm{NAr}\right), 24.4\left(\mathrm{CH}_{3},{ }^{\mathrm{i}} \mathrm{Pr}\right), 26.2(\mathrm{THF}), 27.0\left(\mathrm{CH}_{3}, \mathrm{i} \mathrm{Pr}\right), 44.6(\mathrm{CH}$, iPr), 46.7 ( $\mathrm{CH}, \mathrm{i} \mathrm{Pr}$ ), 115.3 (ortho-C, NAr), 127.7 (meta- $\mathrm{CH}, \mathrm{NAr}$ ), 129.7 (para- $\mathrm{CH}, \mathrm{NAr}$ ), 155.3 (ipso-C, NAr), $160.2\left(\mathrm{CN}_{3}\right)$. Anal Calcd for $\mathrm{C}_{34} \mathrm{H}_{56} \mathrm{~N}_{6} \mathrm{Na}_{2} \mathrm{O}$ (one molecule of THF per dimer was considered, according to the NMR data): C, 66.85; H, 9.24; N, 13.76. Found, C, 67.14; H, 9.22; N, 14.51.

General procedure for kinetic experiments. Kinetic experiments were performed using a Varian FT-400 MHz spectrometer. A standard solution of catalyst 1 in deuterated THF was made. The described kinetic experiments were carried out on the $N, N^{\prime}$-disopropylcarbodiimide $\mathbf{3} \mathbf{a}$ and 4-tbutilaniline $2 c$ to form the corresponding guanidine. Reactions were carried out in J-Young NMR tubes and the reaction rates were measured by monitoring the disappearance of amine (or carbodiimide) and formation of guanidine by ${ }^{1} \mathrm{H}$ NMR spectroscopy at the described intervals over more than three half-lives. All data were processed using Varian integral analysis software. Reaction rates were derived from the plot of $\operatorname{Ln}$ [substrate]o/[substrate] vs time (by fitting data to the eq. Ln[substrate] $0 /[$ substrate] $=$ kobs.t) by using linear trend lines generated by Microsoft Excel software. To obtain Arrhenius and Eyring plots, kinetic analyses were conducted at four different temperatures, each separated by approximately $5-10 \mathrm{~K}$. 
Determination of reaction order with respect aniline $2 \mathrm{c}$ and carbodiimide $3 \mathbf{a}$. The order of the reaction with respect to amine concentration was determined holding the concentration of the other components virtually unaltered, using $1.9 \mathrm{mM}$ concentration solution of catalyst $\mathbf{1}$, and using a carbodiimide to amine molar ratio greater than 10:1. The excess of carbodiimide concentration maintains approximately zero-order conditions. The order of the reaction with respect to the concentration of carbodiimide was studied holding an amine to carbodiimide molar ratio greater than 10:1.

\section{Acknowledgements}

We thank the University of Strathclyde (studentship to ZL), the European Research Council (ERC-STG grant to EH) for the generous sponsorship of this research and the the Spanish Ministerio de Economía y Competitividad (MINECO) project CTQ2014-51912-REDC. We also thank Diamond Light Source for access to 119. A. M., F. C.-H. A. A. gratefully acknowledge financial support from the the Junta de Comunidades de Castilla-La Mancha (project PEII-2014-041-P).

Keywords: magnesiates, cooperative effects, guanidines, homogeneous catalysis, s-block metals

[1] Reviews on Group 2 catalysis: (a) M. S. Hill, D. J. Liptrot, C. Weetman, Chem. Soc. Rev., 2016, 45, 972. (b) S. Harder, Chem. Rev. 2010, 110 3852; 59. (c) A. G. M. Barrett, M. R. Crimmin, M. S. Hill, P. A Procopiou, Proc. R. Soc. A, 2010, 466, 927.

[2] (a) C. Brinkmann, A. G. M. Barrett, M. S. Hill, P. A. Procopiou, J. Am Chem. Soc. 2012, 134, 2193, 57. (b) C. Weetman, M. D. Anker, M. Arrowsmith, M. S. Hill, G. Kociok-Kohn, D. J. Liptrot, M. F. Mahon Chem. Sci., 2016, 7, 628. (c) D. J. Liptrot, M. S. Hill, M. F. Mahon, A. S. S. Wilson, Angew. Chem. Int. Ed., 2015, 54, 13362. (d) M. D. Anker, M. S. Hill, J. P. Lowe, M. F. Mahon, Angew.Chem. Int. Ed., 2015, 54, 10009.

[3] J. Penafield, L. Maron, S. Harder, Angew. Chem. Int. Ed. 2015, 54, 201 (b) J. Intemann, H. Bauer, J. Pahl, L. Maron, S. Harder, Chem. Eur.J., 2015, 21, 11452. (c) J. Intemann, M. Lutz, S. Harder, Organometallics, 2014, 33, 5722.

[4] B. Liu, T. Roisnel, J. F. Carpentier, Y. Sarazin, Angew. Chem. Int. Ed., 2012, 51, 4943

[5] (a) J.-S. Ryu, G. Y. Li, T. J. Marks, J. Am. Chem. Soc., 2003, 125, 12584. (b) D. V. Gribkov, K. C. Hultzsch, F. Hampel, J. Am. Chem. Soc. 2006, 128, 3748 .

[6] A. Hernán-Gómez, T. D. Bradley, A. R. Kennedy, Z. Livingstone, S. D. Robertson, E. Hevia, Chem. Commun., 2013, 49, 8659

[7] (a) T. Klatt, J. T. Markiewicz, C. Saemann, P. Knochel, J. Org. Chem. 2014, 79, 4253. (b) A. Harrison-Marchand, F. Mongin, Chem. Rev. 2013, 113, 7470. (c) A. Harrison-Marchand, F. Mongin, Chem. Rev. 2013, 113, 7563. (d) R. E. Mulvey, S. D. Robertson, Top Organomet Chem, 2014, 45, 103.

[8] For selected references on alkali-metal magnesiates see: (a) N. Boudet, J.R. Lachs, P. Knochel, Org. Lett. 2007, 9, 5525. (b) L. Shi, Y. Chu, P. Knochel, H. Mayr, Angew. Chem. Int. Ed., 2008, 47, 202. (c) A Krasovskiy, V. Krasovskaya, P. Knochel, Angew. Chem. Int. Ed., 2006, 45, 2958. (d) S. H. Wunderlich, C. J. Rohbogner, A. Unsinn, P. Knochel, Org. Process Res. Dev. 2010, 14, 339. (e) D. Tilly, F. Chevallier, F. Mongin, P. C. Gros, Chem. Rev. 2014, 114, 1207. (f) C. Y. Liu, P. Knochel, Org. Lett. 2005, 7, 2543. (b) R. J. Kloetzing, A. Krasovskiy, P.
Knochel Chem. Eur. J. 2006, 13, 215. (g) F. F. Fleming, V. Gudipati, O. W. Steward, Org. Lett. 2002, 4, 659. (h) J. Kondo, A. Inoue, H Shinokubo, K. Oshima, Angew. Chem. Int. Ed. 2001, 40, 2085. (i) P. C. Andrikopoulos, D. R. Armstrong, D. V. Graham, E. Hevia, A. R. Kennedy, R. E. Mulvey, C. T. O'Hara, C. Talmard, Angew. Chem. Int. Ed. 2005, 44, 3459. (j) E. Hevia, G. W. Honeyman, A. R. Kennedy, R. E. Mulvey, D. C. Sherrington, Angew. Chem. Int. Ed. 2005, 44, 68. (k) B. Conway, E. Hevia, A. R. Kennedy, R. E. Mulvey, Chem. Commun 2007, 2864. (I) A. J. Martinez-Martinez, D. R. Armstrong, B. Conway, B. J. Fleming, J. Klett, A. R. Kennedy, R. E. Mulvey, S. D. Robertson, C. T. O'Hara, Chem. Sci. 2014, 5, 771. (m) A. J. Martínez-Martínez, A. R. Kennedy, R. E. Mulvey, C. T. O'Hara, Science, 2014, 346, 834.

[9] For reviews in the area see: (a) C. Alonso-Moreno, A. Antiñolo, F. Carrillo-Hermosilla, A. Otero, Chem. Soc. Rev. 2014, 43, 3406. (b) W.-X. Zhang, L. Xu, Z. Xi, Chem. Commun. 2015, 51, 254. (c) L. Xu, W.-X. Zhang, F. Xi, Organometallics 2015, 34, 1787.

[10] See, for example: (a) R. G. S. Berlinck, A. E. Trindade-Silva, M. F. C Santos, Nat. Prod. Rep. 2012, 29, 1382. (b) D. Castagnolo, S. Schenone, M. Botta, Chem. Rev. 2011, 111, 5247. (c) S. Ekelund, P. Nygren, R. Larsson, Biochem. Pharmacol. 2001, 61, 1183. (d) P. P Toth, Postgrad Med. 2014, 126, 7. (e) D. T. Nash, J. Clin. Pharmacol. 1973, 13, 416. (f) N. Scheinfeld, Dermatol. Online J. 2003, 9, 4. (g) M von Itzstein, Nat. Rev. Drug. Discov. 2007, 12, 967. (h) Y. Hirata, I. Yanagisawa, Y. Ishii, S. Tsukamoto, N. Ito, Y. Isomura, M. Takeda, U.S Patent 1981, 4.283.408. (i) E. Buchdunger, J. Zimmermann, H. Mett, T. Meyer, M. Mueller, B. J. Druker, N. B. Lydon, Cancer Res. 1996, 56, 100. (j) L. Troncone, V. Rufini, Anticancer Res. 1997, 17, 1823. (k) C Loesberg, H. Van Rooij, J. C. Romijm, L. A. Smets, Biochem. Pharmacol. 1991, 42, 793.

[11] See, for example: (a) P. J. Bailey, S. Pace, Coord. Chem. Rev. 2001 214, 91. (b) W. E. Piers, D.J.H. Emslie, Coord. Chem. Rev. 2002, 233, 131. (c) M. P. Coles, Dalton Trans. 2006, 985. (d) P. C. Junk, M. L Cole, Chem. Commun. 2007, 1579. (e) F. T. Edelmann, Adv. Organomet. Chem. 2008, 57, 183. (f) F.T. Edelmann, Adv. Organomet. Chem. 2013, 61, 55. (g) J. Barker, M.Kilner, Coord. Chem. Rev. 1994, 133, 219. (h) F. T. Edelmann, Coord. Chem. Rev. 1994, 137, 403. (i) F. T. Edelmann, Chem. Soc. Rev. 2009, 38, 2253. (j) F.T. Edelmann, Chem. Soc. Rev. 2012, 41, 7657. (k) C. Jones, Coord. Chem. Rev. 2010, 254, 1273. (I) A. A. Trifonov, Coord. Chem. Rev. 2010, 254, 1327.

[12] See, for example: (a) T. Ishikawa, T. Isobe, Chem.-Eur. J. 2002, 8, 553 (b) T. Ishikawa, T. Kumamoto, Synthesis 2006, 737. (c) T. Ishikawa, Superbases for Organic Synthesis: Guanidines, Amidines, Phosphazenes and Organocatalysts, John Wiley \& Sons, 2009. (d) J. E. Taylor, S. D. Bull, J. M. J. Williams, Chem. Soc. Rev. 2012, 41, 2109 (e) D. Leow,C.-H. Tan, Chem.-Asian J. 2009, 4, 488. (f) P. Selig, Synthesis 2013, 703. (g) M. P. Coles. Chem. Commun. 2009, 3659. (h) X. Fu, C.-H. Tan, Chem. Commun. 2011, 47, 8210. (i) A. Avila, R. Chinchilla, E. Gómez-Bengoa, C. Nájera, Eur. J. Org. Chem. 2013, 5085. (j) C. Thomasa, B. Bibal, Green Chem. 2014, 16, 1687.

[13] (a) M. K. T. Tin, N. Thirupathi, G. P. A. Yap, D. S. Richeson, J. Chem Soc., Dalton Trans. 1999, 2947. (b) M. K. T. Tin, G. P. A. Yap, D. S. Richeson, Inorg. Chem. 1998, 37, 6728. (c) E. W. Thomas, E. E. Nishizawa, D. C. Zimmermann, D. J. Williams, J. Med. Chem. 1989, 32, 228.

[14] (a) T.-G. Ong, G. P. A. Yap, D. S. Richeson, J. Am. Chem. Soc., 2003, 125, 8100. (b) A. Grirrane, H. Garcia, E. Álvarez, Beilstein J. Org. Chem., 2013, 9, 1455. (c) S. Zhou, S. Wang, G. Yang, Q. Li, L. Zhang, Z. Yao, Z. Zhou, H.-B. Song, Organometallics 2007, 26, 3755. (d) F Han, Q. Teng, Y. Zhang, Y. Wang, Q. Shen, Inorg. Chem., 2011, 50, 2634. (e) L. Xu, Z. Wang, W.-X. Zhan and Z. Xi, Inorg. Chem., 2012, 51, 11941. (f) J. Romero-Fernández, F. Carrillo-Hermosilla, A. Antiñolo, C. Alonso-Moreno, A. M. Rodríguez, I. López-Solera, A. Otero, Dalton Trans. 2010, 39, 6419. (g) D. Elorriaga, F. Carrillo-Hermosilla, A. Antiñolo, F. J. Suárez, I. López-Solera, R. Fernández-Galán, E. Villaseñor, Dalton Trans., 2013, 42, 8223. 
[15] T.-G. Ong, J. S. O’Brien, I. Korobkov, D. S. Richeson, Organometallics, 2006, 25, 4728.

[16] (a) C. Alonso-Moreno, F. Carrillo-Hermosilla, A. Garcés, A. Otero, I. López-Solera, A. M. Rodríguez, A. Antiñolo, Organometallics 2010, 29 2789. (b) D. Elorriaga, F. Carrillo-Hermosilla, A. Antiñolo, I. LópezSolera, R. Fernández-Galán, A. Serrano, E. Villaseñor, Eur. J. Inorg. Chem. 2013, 2940. (c) A. Baishya, M. Kr. Barman, T. Peddarao, S. Nembenna, J. Organomet. Chem. 2014, 769, 112. (d) J. R. Lachs, A G. M. Barrett, M. R. Crimmin, G. Kociok-Köhn, M. S. Hill, M. F. Mahon, P. A. Procopiou, Eur. J. Inorg. Chem. 2008, 4173.

[17] To best of our knowledge, only three examples of magnesium complexes have been described so far in the literature as catalysts for guanylation reactions: $\mathrm{MgnBu}_{2},\left[\mathrm{MgBz}_{2}(\mathrm{THF})_{2}\right]$, and an $\mathrm{N}$-heterocyclic carbene $(\mathrm{NHC})$ supported magnesium amide, see references $16 \mathrm{a}, 16 \mathrm{~b}$ and $16 \mathrm{c}$ respectively.

[18] M. R. Crimmin, A. G.M. Barrett, M. S. Hill, P. B. Hitchcock, P. A. Procopiou, Organometallics 2008, 27, 497.

[19] S. E. Baillie, W. Clegg, P. Garcia-Alvarez, E. Hevia, A. R. Kennedy, J. Klett, L. Russo, Chem. Commun, 2011, 47, 388.

[20] (a) X. Zhang, C. Wang, C. Qian, F. Han, F. Xu, Q. Shen, Tetrahedron, 2011, 67, 8790. (b) X. Zhu, Z. Du, F. Xu, Q. Shen, J. Org. Chem., 2009 $74,6347$.

[21] For other examples of structurally defined tris(amido)magnesiates see: (a) E. Hevia, F. R. Kenley, A. R. Kennedy, R. E. Mulvey, R. B. Rowlings Eur. J. Inorg. Chem. 2003, 3347. (b) G C. Forbes, A. R. Kennedy, R. E. Mulvey, P. J. A. Rodger, R. B. Rowlings, J. Chem. Soc., Dalton Trans. 2001, 1477. (c) W. Clegg, K. W. Henderson, R. E. Mulvey, P. A. O'Neil, J. Chem. Soc., Dalton Trans., 1994, 769. (d) B. J. Fleming, P. GarcíaÁlvarez, E. Keating, A. R. Kennedy, C. T. O'Hara, Inorg. Chim. Acta, 2012, 384, 154. (e) J. Francos, B. J. Fleming, P. García-Álvarez, A. R. Kennedy, K. Reilly, G. M. Robertson, S. D. Robertson, C. T. O'Hara, Dalton Trans., 2014, 43, 14424

[22] D. Barr, W. Clegg, L. Cowton, L. Horsburgh, F. M. Mackenziec, R. E. Mulvey, J. Chem. Soc., Chem. Comm., 1995, 891.

[23] X-ray analysis shows only three non equivalent anilide fragments with $\mathrm{R}, \mathrm{S}, \mathrm{R}, \mathrm{S}$ configuration for N4, N6, N2 and N1. However, during the identification of the hydrogen atoms on the Fourier map possible disorder was noticed, precluding an accurate establishment of the rea configuration. Thus, two different possibilities can be found, a diastereomer with a configuration of the type R, R, R, S which would show six inequivalent anilide fragments or a mixture of diastereomers such as $R, S, R, S$ and $R, R, S, S$ which similarly would display a total of six signals for the anilide fragments.

[24] R. Neufeld, D. Stalke, Chem. Sci., 2015, 6, 3354
[25] For examples of sodium magnesiates displaying a SSIP structure in which sodium is solvated by THF molecules see: (a) D. R. Armstrong W. Clegg, A. Hernan-Gomez, A. R. Kennedy, Z. Livingstone, S. D. Robertson, L. Russo, E. Hevia, Dalton Trans., 2014, 43, 4361. (b) V. L. Blair, W. Clegg, A. R. Kennedy, Z. Livingstone, L. Russo, E. Hevia, Angew. Chem., Int. Ed., 2011, 50, 9857

[26] Supporting Information for synthesis and spectroscopic characterization

[27] For other examples of structurally defined guanidinates where a similar rearrangement has taken place see references $14 \mathrm{~g}, 16 \mathrm{a}, 16 \mathrm{~d}$, and $\mathrm{W}$. X. Zhang, M. Nishiura, Z. Hou, Chem. Eur. J. 2007, 13, 4037.

[28] G. J. Moxey, A. J. Blake, W. Lewis, D. L. Kays, Eur. J. Inorg. Chem. 2015, 5892

[29] A similar motif has been also reported by Chang for the reaction of $\mathrm{Mg}\left[\mathrm{N}(i \mathrm{Pr})_{2}\right]_{2}$ with 2 eq DIC, see: B. Srinivas, C.-C. Chang, C.-H. Chen M. Y. Chiang, I.-T. Chen, Y. Wang, G.-H. Lee, J. Chem. Soc., Dalton Trans., 1997, 957.

[30] G. R. Giesbrecht, A. Shafir, J. Arnold, J. Chem. Soc., Dalton Trans., 1999, 3601

[31] C. N. Rowley, T.-G. Ong, J. Priem, T. K. Woo, D. S. Richeson, Inorg Chem., 2008, 47, 9660.

[32] S. E. Baillie, W. Clegg, P. Garcıa-Álvarez, E. Hevia, A. R. Kennedy, J. Klett, L. Russo, Organometallics, 2012, 31, 5131.

[33] For an example of anionic activation of magnesium reagents by forming mixed ammonium-magnesiate salts see: C. Vidal, J. Garcia-Alvarez, A Hernan-Gomez, A. R. Kennedy, E. Hevia, Angew. Chem. Int. Ed. 2014 53, 5969.

[34] A. Mukherjee, T. K. Sen, S. K. Mandal, B. Maity, D. Koley, RSC Adv. 2013, 3, 1255.

[35] J. H. Espenson, Chemical kinetics and reaction mechanisms, $2^{\text {nd }}$ ed. McGraw-Hill: New York, 1995.

[36] (a) J. F. Dunne, D. B. Fulton, A. Ellern, A. D. Sadow, J. Am. Chem. Soc 2010, 132, 17680; (b) C.Brinkmann, A. G. M. Barrett, M. S. Hill, P. A Procopiou, J. Am. Chem. Soc. 2012, 134, 2193

[37] J. Klett, W. Clegg, B. Conway, A. R. Kennedy, R. E. Mulvey and L. Russo, Eur. J. Inorg. Chem., 2011, 721.

[38] (a) T. G. Ong, G. P. A. Yap, D. S. Richeson, J. Am. Chem. Soc. 2003, 125, 8100; (b) Q. Li, S. Wang, S. Zhou, G. Yang, X. Zhu, Y. Liu, J. Org Chem. 2007, 72, 6763; (c) S4. Z. Du, W. Li, X. Zhu, F. Xu, Q. Shen, J. Org. Chem. 2008, 73, 8966; (d) M. P. Coles, P. B. Hitchcock, Chem. Commun. 2002, 2794.

[39] CrysAlisPro; Oxford Diffraction: Oxford, UK 2008.

[40] G. Sheldrick, Acta Cryst. 2015, C71, 3-8. 
Entry for the Table of Contents (Please choose one layout)

Layout 1:

\section{FULL PAPER}

\section{Magnesium activATES:}

Showing enhanced catalytic ability compared to their homometallic components, mixed $\mathrm{Na} / \mathrm{Mg}$ complexes effectively catalyse guanylation of a range of amines under mild reaction conditions, the key for which is magnesium's anionic activation by installing it within a sodium magnesiate platform.

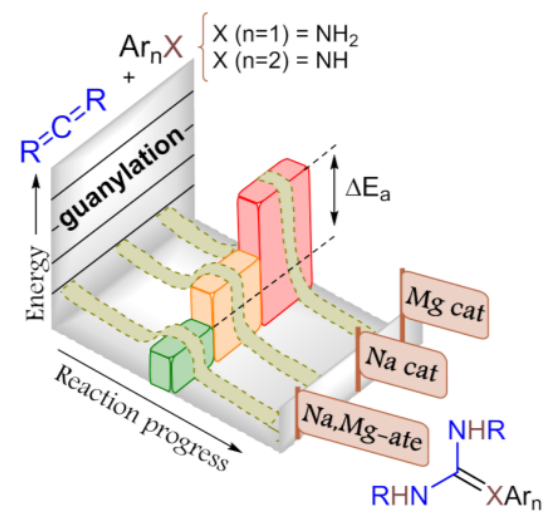

M. De Tullio, A. Hernán-Gómez, Z. Livingstone, W. Clegg, A. R. Kennedy, R. W. Harrington, A. Antiñolo, A. Martínez, F. Carrillo-Hermosilla* and E. Hevia*

Page No. - Page No.

Structural and mechanistic insights into s-block bimetallic catalysis: sodium magnesiate catalysed guanylation of amines

Layout 2:

\section{FULL PAPER}

((Insert TOC Graphic here; max. width: $11.5 \mathrm{~cm}$; max. height: $2.5 \mathrm{~cm})$ )
Author(s), Corresponding Author(s)*

Page No. - Page No.

Title 